\title{
Neurite outgrowth inhibitory levels of organophosphates induce tissue transglutaminase activity in differentiating N2a cells: evidence for covalent adduct formation
}

\author{
Ibtesam S. Almami ${ }^{1,2} \cdot$ Maha A. Aldubayan ${ }^{1,3}$. Shatha G. Felemban ${ }^{1,4} \cdot$ Najiah Alyamani $^{1,5} \cdot$ Richard Howden $^{1}$. \\ Alexander J. Robinson ${ }^{1,6} \cdot$ Tom D. Z. Pearson $^{1}$ - David Boocock ${ }^{1}$ - Alanood S. Algarni ${ }^{1,7}$ • A. Christopher Garner ${ }^{1}$. \\ Martin Griffin ${ }^{8}$ - Philip L. R. Bonner ${ }^{1}$. Alan J. Hargreaves ${ }^{1}$ (1)
}

Received: 19 January 2020 / Accepted: 14 July 2020 / Published online: 4 August 2020

(c) The Author(s) 2020

\begin{abstract}
Organophosphate compounds (OPs) induce both acute and delayed neurotoxic effects, the latter of which is believed to involve their interaction with proteins other than acetylcholinesterase. However, few OP-binding proteins have been identified that may have a direct role in OP-induced delayed neurotoxicity. Given their ability to disrupt $\mathrm{Ca}^{2+}$ homeostasis, a key aim of the current work was to investigate the effects of sub-lethal neurite outgrowth inhibitory levels of OPs on the $\mathrm{Ca}^{2+}$-dependent enzyme tissue transglutaminase (TG2). At 1-10 $\mu \mathrm{M}$, the OPs phenyl saligenin phosphate (PSP) and chlorpyrifos oxon (CPO) had no effect cell viability but induced concentration-dependent decreases in neurite outgrowth in differentiating N2a neuroblastoma cells. The activity of TG2 increased in cell lysates of differentiating cells exposed for $24 \mathrm{~h}$ to PSP and chlorpyrifos oxon CPO $(10 \mu \mathrm{M})$, as determined by biotin-cadaverine incorporation assays. Exposure to both OPs ( 3 and/or $10 \mu \mathrm{M})$ also enhanced in situ incorporation of the membrane permeable substrate biotin-X-cadaverine, as indicated by Western blot analysis of treated cell lysates probed with ExtrAvidin peroxidase and fluorescence microscopy of cell monolayers incubated with FITC-streptavidin. Both OPs $(10 \mu \mathrm{M})$ stimulated the activity of human and mouse recombinant TG2 and covalent labelling of TG2 with dansylamine-labelled PSP was demonstrated by fluorescence imaging following SDS-PAGE. A number of TG2 substrates were tentatively identified by mass spectrometry, including cytoskeletal proteins, chaperones and proteins involved protein synthesis and gene regulation. We propose that the elevated TG2 activity observed is due to the formation of a novel covalent adduct between TG2 and OPs.
\end{abstract}

Keywords Organophosphate toxicity $\cdot$ Neurite outgrowth $\cdot$ Covalent adduct $\cdot$ Tissue transglutaminase

Alan J. Hargreaves

alan.hargreaves@ntu.ac.uk

1 School of Science and Technology, Nottingham Trent University, Nottingham NG11 8NS, UK

2 Department of Biology, College of Science, Qassim University, Al-Qassim, Saudi Arabia

3 Department of Pharmacology and Toxicology, College of Pharmacy, Qassim University, Al-Qassim, Saudi Arabia

4 Department of Medical Laboratory Science, Fakeeh College for Medical Science, Jeddah, Saudi Arabia
5 Department of Biology, Faculty of Science, University of Jeddah, Jeddah, Kingdom of Saudi Arabia

6 Department of Life Sciences, School of Health Sciences, Birmingham City University, City South Campus, Edgbaston B15 3TN, UK

7 Department of Pharmacology and Toxicology, Faculty of Pharmacy, Umm Al-Qura University, Mekkah, Saudi Arabia

8 Department of Life and Health Sciences, Aston University, Birmingham B4 7ET, UK 


\section{Introduction}

It is well established that many commercially available organophosphorous compounds (OPs) used as oil additives (e.g., tricresyl phosphate; TCP) and insecticides (e.g., chlorpyrifos; CPF), inhibit the activities of serine hydrolases such as acetyl and butyryl cholinesterase (Aldridge 1954; Chambers and Levi 1992; Gupta 2006; Kamanyire and Karralliede 2004). However, they are also capable of inducing delayed neurodegenerative and/or developmental effects through covalent interactions with non-cholinesterase protein targets (Ray and Richards 2001; Hargreaves 2012; Sánchez-Santed et al. 2016).

For example, TCP induces a neurodegenerative condition known as OP-induced delayed neuropathy (OPIDN), which was associated with a major outbreak of Ginger Jake poisoning during the years of prohibition in the USA (Bishop and Stewart 1930; Zeligs 1938). The clinical signs of OPIDN do not appear until up to several weeks following exposure and are characterised by wrist drop and a flaccid paralysis (Abou-Donia and Lapadula 1990; Hargreaves 2012). The onset of OPIDN is preceded by a number of early molecular lesions, such as irreversible inhibition of neuropathy target esterase (NTE), disrupted $\mathrm{Ca}^{2+}$ homeostasis, proteolytic degradation and altered phosphorylation of cytoskeletal proteins (Hargreaves 2012) in the central and peripheral nervous systems. It is known that TOCP (i.e., the ortho isomer of TCP) is the main inducer of OPIDN by TCP formulations (AbouDonia and Lapadula 1990; Harris et al. 1997) following its metabolic conversion into saligenin cyclic-o-tolyl phosphate (SCOTP), which is a more potent inhibitor of NTE but, unlike OPs used as pesticides, a weak inhibitor of AChE (Lotti and Johnson 1978). A number of cell culture studies have shown that phenyl saligenin phosphate (PSP), a structural analogue of SCOTP, inhibits the outgrowth of neurites in differentiating neuroblastoma cells in association with complete inhibition of NTE, increased activation of ERK 1/2, and transient hyperphosphorylation followed by a reduction in the protein levels of neurofilament heavy chain (Hargreaves et al. 2006).

On the other hand, the main acute toxicity target of $\mathrm{CPF}$, after its conversion to chlorpyrifos oxon (CPO) by cytochrome $\mathrm{P} 450$-mediated desulphuration, is $\mathrm{AChE}$, the inhibition of which leads to the accumulation of acetylcholine and, potentially, subsequent cholinergic stress (Saunders et al. 2012; Hargreaves 2012). However, CPF also exhibits delayed neurotoxic effects in developing rodent brains, following exposure at doses causing non-acute inhibition of AChE activity but able to inhibit protein and DNA synthesis, thus affecting the normal development of the brain (Grandjean and Landrigan 2014; Lee et al. 2015).
It has been shown that $\mathrm{CPF}$ and its metabolites induce neurodevelopmental toxicity in embryonic stem cell models of neural differentiation, as indicated by characteristic patterns of disruption of differentiation marker gene expression, via a mechanism that is dependent on the expression of NTE but not on the inhibition of its esterase activity (Estevan et al. 2014; Sogorb et al. 2016). In vitro studies have also shown that CPF and CPO inhibit neurite outgrowth (Howard et al. 2005; Sachana et al. 2001, 2008; Yang et al. 2008; Flaskos et al. 2011), proliferation and DNA synthesis in neuronal and glial cell lines (Garcia et al. 2001; Qiao et al. 2001). CPF interferes with the AChE transduction cascade (Yang et al. 2008), and with transcriptional events by affecting AP-1 and SP1 nuclear transcription factors that are involved in neuronal cell differentiation (Garcia et al. 2001; Crumpton et al. 2000), and with neurotransmission (Slotkin and Seidler 2007). CPF also affects the adenylate cyclase signalling pathway (Garcia et al. 2001) that controls the formation of cAMP, which acts as an important switch signal to activate cell differentiation (Cooper and Hausman 2004).

Glial cells exposed to CPF exhibit an increase in ROS formation (Saulsbury et al. 2009). The creation of ROS is not associated with direct chemical actions; rather, it involves the effects of CPF on cell metabolism (Crumpton et al. 2000). Studies on cultured cells have indicated that elevated levels of ROS can disrupt $\mathrm{Ca}^{2+}$ homeostasis (Xu et al. 2011), which could consequently interfere with the regulation of $\mathrm{Ca}^{2+}$ dependent proteins.

Of interest to the present study are the transglutaminases (TGs), which comprise a family of $\mathrm{Ca}^{2+}$ dependent enzymes that catalyse the post-translational modification of proteins (Lorand and Graham 2003; Bergamini et al. 2011). Tissue TG-associated enzymatic functions, such as the covalent cross-linking of proteins and amine incorporation into proteins, are associated with tissue stabilization and with the prevention of and protection from bodily injury. However, TG2 activity is inappropriately activated in some neuropathologies (Kim et al. 2002), thus making it a potential therapeutic target.

Tissue transglutaminase (TG2) plays an important role in several processes that occur in normal neural tissues. For example, it is involved in the plasticity and stabilization of the synapse in the CNS by formation of protease-resistant protein crosslinks (Festoff et al. 2001). It is also involved in the suppression of catecholamine release from neurons, generating a negative feedback that will also prevent an excessive release of transmitters. Tissue TG expression and transamidase activity are required for neurite outgrowth in differentiating neuroblastoma cells (Tucholski et al. 2001) and rat cerebellar granule neurons (Mahoney et al. 2000). It was suggested that this effect involved TG2-mediated increases in cAMP production due to enhanced activation of cAMP response element binding protein (CREB) 
(Tucholski and Johnson 2003), a transcription factor that modulates synaptic plasticity, cell survival and cell differentiation (Duman et al. 2000). The presence of TG2 and its cross-linking activity have also been detected in the growth cones of neurites produced by cultured cerebellar granule neurons, in which several substrates for TG2 have been identified (Sugitani et al. 2006).

As TG2 is a $\mathrm{Ca}^{2+}$ dependent enzyme, its activity could be disrupted by altered $\mathrm{Ca}^{2+}$ homeostasis, as well as by elevated levels of ROS, phenomena which are known to be induced by OPs (Giordano et al. 2007; Ientile et al. 2007). Preliminary studies by our group have shown that exposure to PSP results in disruption of TG2 activity monitored in lysates from mitotic $\mathrm{N} 2 \mathrm{a}$ and $\mathrm{HepG} 2$ cells after $24 \mathrm{~h}$ exposure. It is also interesting to note that TG2 protein levels suffered a decrease in PSP-treated N2a cells but increased in HepG2 cells, suggesting that the changes in the protein levels could have been responsible for the differences in the observed effects (Harris et al. 2009a).

Given the emerging role of TG2 in neurite outgrowth and neural differentiation, either through its expression or its catalytic activities, coupled with its potential involvement in neurotoxicity, the aim of this study was to explore the modulation of TG2 activity by exposure to the OPs PSP and $\mathrm{CPO}$ in differentiating mouse $\mathrm{N} 2 \mathrm{a}$ neuroblastoma cells.

\section{Materials and methods}

Unless otherwise specified, all reagents were purchased from Sigma Aldrich Company Ltd (Poole, UK). Dulbecco's modified Eagle's medium (DMEM) with $4.5 \mathrm{~g} / \mathrm{L}$ glucose and $2 \mathrm{mM} \mathrm{L}$-glutamine was obtained from Lonza (Viviers, Belgium). Cell culture plastic ware and other cell culture reagents were purchased from Scientific Laboratory Supplies (SLS, Wilford, UK). The N2a and C6 cell lines were from obtained from ATCC and ECACC, respectively.

\section{Maintenance and differentiation of N2a cells}

Cells were grown as monolayers in T75 flasks with $20 \mathrm{ml}$ growth medium (high glucose DMEM supplemented with $10 \% \mathrm{v} / \mathrm{v}$ foetal bovine serum (FBS), $2 \mathrm{mM} \mathrm{L}$-glutamine, penicillin (100 units $/ \mathrm{ml})$ and streptomycin $(100 \mu \mathrm{g} / \mathrm{ml})$ ), using a humidified incubator at $37^{\circ} \mathrm{C}$ and an atmosphere of $5 \% \mathrm{CO}_{2} / 95 \%$ air. Cells were sub-cultured on reaching approximately $80-90 \%$ confluence. For differentiation experiments, cells were seeded at 50,000 cells $/ \mathrm{ml}$ into 24 -well plates $(25,000$ cells/well), T25 (500,000 cells) or T75 flasks ( 2 million cells) in growth medium and allowed $24 \mathrm{~h}$ recovery before the induction of cell differentiation in the absence and presence of OPs. For this, stock solutions of OPs were dissolved in dimethyl sulphoxide (DMSO) and diluted in pre-warmed serum-free medium containing $0.3 \mathrm{mM}$ dibutyryl cAMP, immediately before use, to final concentrations of $1-10 \mu \mathrm{M}$. The final concentration of DMSO was $0.5 \%(\mathrm{v} / \mathrm{v})$, which was also added to control cells. In some experiments, as described below, to confirm the involvement of TG2, cells were pre-incubated for $1 \mathrm{~h}$ with the irreversible TG2 specific inhibitor Z-DON-ValPro-Leu-OMe (ZDON; Zedira, GmbH, Germany), prior to the induction of cell differentiation. This was added at a final concentration of $100 \mu \mathrm{M}$ (Almami et al. 2014).

\section{Measurement of cell viability and neurite outgrowth}

To determine the effects of OPs on cell viability, cells were seeded in T25 flasks (500,000 cells in $10 \mathrm{ml}$ growth medium) and cultured for $24 \mathrm{~h}$ prior to the induction of differentiation in the absence and presence of OPs $(1-10 \mu \mathrm{M})$, as described above. Following exposure, the cells were detached and viable cell counts determined by Trypan Blue exclusion using a TC-20 automated cell counter (BioRad, Hemel Hempstead, UK) after a 1:1 dilution with Trypan Blue solution $(0.4 \% \mathrm{v} / \mathrm{v}$; BioRad, Hemel Hempstead, UK).

Neurite outgrowth was monitored by high content analysis (HCA) of monolayers immunofluorescently stained with monoclonal antibody $2 \mathrm{G} 10$, which recognises $\beta$ III-tubulin, using an ImageXpress ${ }^{\text {MICRO }}$ imaging system (Molecular Devices, Oxford, UK), as described previously (Sindi et al. 2016). Significant outgrowth was recorded for any cell with at least one stained neurite longer than $5 \mu \mathrm{m}$ in length.

\section{Preparation of cell lysates}

After the appropriate treatments, cell monolayers were rinsed twice with $2 \mathrm{ml}$ of chilled PBS, lysed with $500 \mu \mathrm{l}$ of ice-cold lysis buffer consisting of $50 \mathrm{mM}$ Tris buffer $\mathrm{pH}$ $8.0,0.5 \%(\mathrm{w} / \mathrm{v})$ sodium deoxycholate, $0.1 \%(\mathrm{v} / \mathrm{v})$ protease inhibitor cocktail III (Millipore, Watford, UK) and 1\% (v/v) HALT $^{\text {TM }}$ Phosphatase Inhibitor Cocktail (1:100; Thermo Fisher Scientific, Paisley, UK). Cell lysates were scraped and clarified by centrifugation at $4{ }^{\circ} \mathrm{C}$ for $20 \mathrm{~min}$ at $14000 \times g$. Supernatants were collected and stored at $-20{ }^{\circ} \mathrm{C}$. Protein concentration was measured by the bicinchoninic acid (BCA) protein assay, based on the method of Stoscheck (1990) using a kit from Sigma Aldrich (Poole, UK). For Western blot analysis, cell monolayers were rinsed as above, then lysed with $500 \mu \mathrm{l}$ of $0.1 \%$ (w/v) sodium dodecyl sulphate (SDS) in PBS (pre-heated to $100{ }^{\circ} \mathrm{C}$ ), after which the suspension was heated at $100{ }^{\circ} \mathrm{C}$ for $5 \mathrm{~min}$ and then centrifuged at $100,000 \mathrm{~g}$ for $30 \mathrm{~min}$, before supernatants were collected and stored at $-20^{\circ} \mathrm{C}$. 


\section{Measurement of TG2-mediated amine incorporation in cell lysates}

Biotin-cadaverine assays were performed on cell lysates by the method of Slaughter et al. (1992) as modified by Lilley et al. (1998). For this, 96-well microtitre plates (Nunc Maxisorp; SLS, Wilford, UK) were coated overnight at $4{ }^{\circ} \mathrm{C}$ with $\mathrm{N}^{\prime}, \mathrm{N}$ 'dimethylcasein $(10 \mathrm{mg} / \mathrm{ml}$ in $100 \mathrm{mM}$ Tris buffer $\mathrm{pH} 8.0 ; 250 \mu \mathrm{l} /$ well). The plate was washed twice with distilled water and blocked with $250 \mu \mathrm{l}$ of $3 \%(\mathrm{w} / \mathrm{v})$ BSA in $0.1 \mathrm{M}$ Tris buffer, $\mathrm{pH} 8.0$ and incubated for $30 \mathrm{~min}$ at $37^{\circ} \mathrm{C}$. The plate was washed twice before adding $150 \mu \mathrm{l}$ of $100 \mathrm{mM}$ Tris buffer, $\mathrm{pH}$ 8.0, containing $225 \mu \mathrm{M}$ biotincadaverine (Fisher Scientific, Loughborough, UK), with $2 \mathrm{mM} \beta$-mercaptoethanol and either $6.67 \mathrm{mM}$ calcium chloride to activate or $13.3 \mathrm{mM}$ EDTA to inactivate TG2. The reaction was started by the addition of $50 \mu \mathrm{l}$ of samples or positive control (50 ng Guinea pig liver TG2) and negative control (Tris buffer). After incubation for $1 \mathrm{~h}$ at $37^{\circ} \mathrm{C}$, plates were washed as before, after which $200 \mu \mathrm{l}$ of $100 \mathrm{mM}$ Tris buffer $\mathrm{pH}$ 8.0, containing horseradish peroxidase (HRP)conjugated ExtrAvidin ${ }^{\mathrm{TM}}$ (1:500 dilution) were added to each well and the plate incubated at $37^{\circ} \mathrm{C}$ for $45 \mathrm{~min}$ then washed as before. The plates were developed by incubation at room temperature for $15 \mathrm{~min}$ with $200 \mu \mathrm{l}$ of freshly made developing buffer $\left(7.5 \mu \mathrm{g} / \mathrm{ml} \mathrm{3,} 3^{\prime}, 5,5^{\prime}\right.$ tetramethylbenzidine and $0.0005 \%(\mathrm{v} / \mathrm{v}) \mathrm{H}_{2} \mathrm{O}_{2}$ in $100 \mathrm{mM}$ sodium acetate $\mathrm{pH}$ 6.0. The reaction was terminated by adding $50 \mu \mathrm{l}$ of $5.0 \mathrm{M}$ sulphuric acid and the absorbance read at $450 \mathrm{~nm}$. One unit of TG2 was defined as a change in absorbance at $450 \mathrm{~nm}$ of 1.0 per hour. Each experiment was performed in triplicate.

\section{Measurement of TG2-mediated amine incorporation in situ}

N2a cells were seeded into ibidi $\mu$-slide cell culture treated 8-well chamber slides (Thistle Scientific, Glasgow, UK), at $50,000 \mathrm{cells} / \mathrm{ml}$, adding $300 \mu \mathrm{l}$ of medium per well, and cultured for $24 \mathrm{~h}$ in growth medium. Cells were then treated for $1 \mathrm{~h}$ with or without the TG2 inhibitors Z-DON $(100 \mu \mathrm{M})$ and induced to differentiate as described above by the addition of differentiation medium containing either 3 or $10 \mu \mathrm{M}$ PSP or $10 \mu \mathrm{M} \mathrm{CPO}$ for $24 \mathrm{~h}$. During the last $4 \mathrm{~h}$ of differentiation, $1 \mathrm{mM}$ biotin-X-cadaverine (5-(( $N$-(biotinoyl)amino) hexanoyl)amino) pentylamine), trifluoroacetic acid salt; Fisher Scientific, Loughborough, UK) was added. Following treatment, cells were fixed with $3.7 \%$ (w/v) paraformaldehyde in PBS for $15 \mathrm{~min}$ at room temperature, before being permeabilised with $0.1 \%$ (v/v) Triton-X100 in PBS for $15 \mathrm{~min}$ at room temperature. Each of the above steps was followed by three 5 min washes with PBS. Cell monolayers were blocked by incubation with 3\% (w/v) BSA in PBS for $1 \mathrm{~h}$ at room temperature, after which biotin-X-cadaverine incorporation was detected by incubation with fluorescein isothiocyanate (FITC)-conjugated ExtrAvidin ${ }^{\circledR}$ (green fluorescence) diluted 1:200 in blocking buffer, for $1 \mathrm{~h}$ followed by 3 PBS washes, as described above. Nuclei were stained with blue fluorescence (DAPI; Invitrogen, UK) and images viewed in an epifluorescence microscope.

\section{In situ labelling for gel based detection of proteins serving as substrates for TG2}

For this, N2a cell monolayers were induced to differentiate in T75 flasks ( 2 million cells per flask) in the presence and absence of OPs, adding $1 \mathrm{mM}$ biotin-X-cadaverine (Fisher Scientific, Loughborough, UK) for the last $4 \mathrm{~h}$ of differentiation. Cell monolayers were lysed as described by Singh et al. (1995), after which proteins in cell lysates were subjected to SDS-PAGE (40 $\mu \mathrm{g} / \mathrm{well}$ ) and transferred to nitrocellulose membranes (Laemmli, 1970; Towbin et al. 1979). The biotin-cadaverine labelled proteins were detected by probing blots with ExtrAvidin ${ }^{\circledR}$-HRP and visualized by enhanced chemiluminescence (ECL). In some experiments, biotincadaverine labelled proteins were enriched using CaptAvi$\operatorname{din}^{\mathrm{TM}}$ agarose (Life Technologies Ltd., Paisley, UK) prior to SDS-PAGE, as described by Almami et al. (2014).

\section{Proteomic analysis of biotin-cadaverine labelled proteins}

Following labelling with $1 \mathrm{mM}$ biotin-X-cadaverine, biotincadaverine labelled proteins were extracted, as described above. The proteins labelled with biotin- cadaverine were purified using CaptAvidin ${ }^{\mathrm{TM}}$ agarose (Life Technologies Ltd., Paisley, UK) prior to polyacrylamide gel electrophoresis in the presence of SDS (SDS-PAGE) (Almami 2014). Protein bands were visualized using InstantBlue protein stain. CaptAvidin-captured proteins with molecular weights matching bands showing increased labelling on gels of lysates from cells differentiated in the presence of PSP that was attenuated by pre-treatment with ZDON, were excised and subjected to in gel digestion, as described by Aldubayan et al. (2017). Briefly, gel bands were excised from the gel and cut into small pieces using a sterile scalpel. The gel pieces were de-stained with freshly prepared $100 \%$ methanol and $50 \mathrm{mM}\left(\mathrm{NH}_{4}\right) \mathrm{HCO}_{3}(1: 1 \mathrm{v} / \mathrm{v})$. Protein bands were subjected to reduction and alkylation, by sequential incubation with $25 \mathrm{mM}$ DTT in $50 \mathrm{mM}\left(\mathrm{NH}_{4}\right) \mathrm{HCO}_{3}$ followed by $55 \mathrm{mM}$ iodoacetamide in $50 \mathrm{mM}\left(\mathrm{NH}_{4}\right) \mathrm{HCO}_{3}$ solution. The gel pieces were then processed for trypsin digestion (Trypsin Gold; Promega, Southampton, UK) over night at $37{ }^{\circ} \mathrm{C}$. The reaction was terminated by adding $0.5 \%(\mathrm{v} / \mathrm{v})$ trifluroacetic acid (TFA) to a final concentration of $0.5 \%$ $(\mathrm{v} / \mathrm{v})$ and digested proteins were recovered in the supernatant following centrifugation. 
a

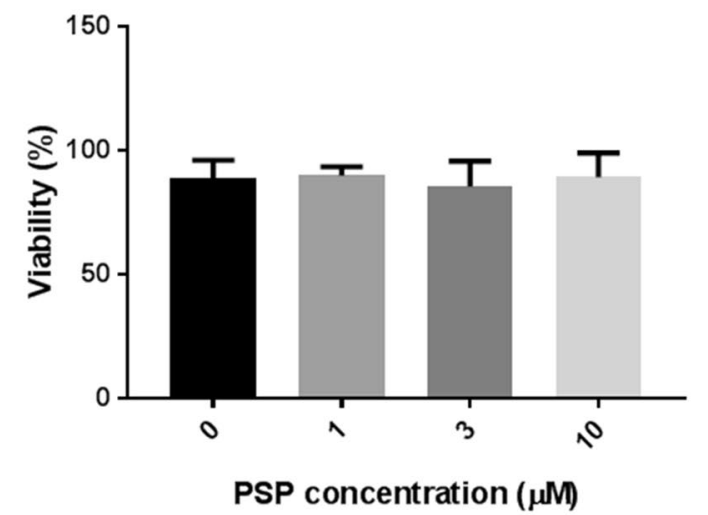

C

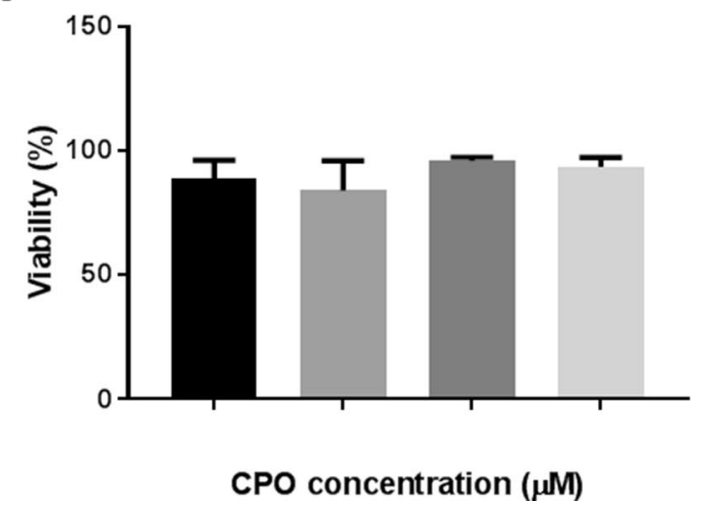

Fig. 1 Effects of PSP and CPO on the viability and differentiation of N2a cells. N2a cells were induced to differentiate for $24 \mathrm{~h}$ in the absence and presence of PSP $(\mathbf{a}, \mathbf{b})$ and CPO $(\mathbf{c}, \mathbf{d})$ at $1-10 \mu \mathrm{M}$. They were then either detached and incubated with Trypan Blue solution to determine cell viability $(\mathbf{a}, \mathbf{c})$ or fixed and stained by indirect

\section{Mass spectrometry and protein identification}

The full profiling of enriched biotin-cadaverine proteins was achieved by LC-MS/MS. Briefly, samples were injected by trap-elute $(4 \mu \mathrm{L})$ using an Eksigent $425 \mathrm{LC}$ system (trap: YMC triart $\mathrm{C}_{18} 0.3 \times 5 \mathrm{~mm}, 300 \mu \mathrm{m}$ ID. Analytical column: YMC Triart $\mathrm{C}_{18} 150 \times 0.3 \mathrm{~mm}, 3 \mu \mathrm{m}, 5 \mu \mathrm{L} /$ min) into a SCIEX TripleTOF 6600 mass spectrometer in Information Dependent Acquisition (IDA, top 30) mode via gradient elution (mobile phase A: $0.1 \%$ formic acid; $\mathrm{B}$ : acetonitrile in $0.1 \%$ formic acid) over $87 \mathrm{~min}$ ( $2 \%$ to $30 \% \mathrm{~B}$ over $68 \mathrm{~min} ; 40 \% \mathrm{~B}$ at $72 \mathrm{~min}$ followed by column wash and re-equilibration) (Aldiss et al. (2019). Mass spectrometry raw data were processed using ProteinPilot 5.02 (SCIEX, Warrington, UK) against the SwissProt mouse database (January 2019) and 1\% FDR protein cutoff applied. b

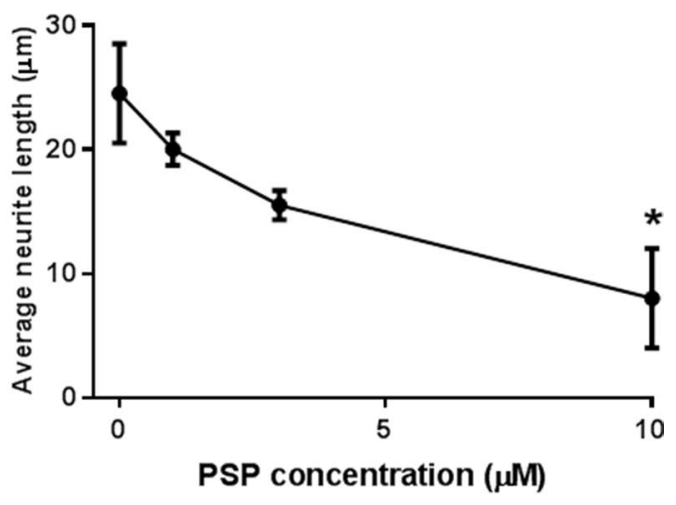

d

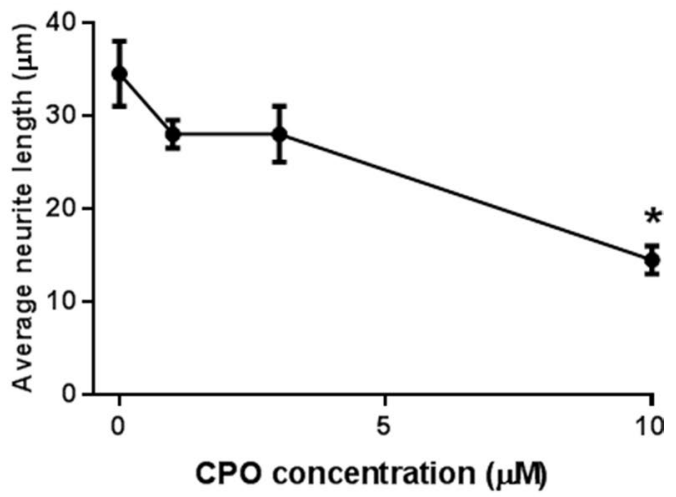

immunofluorescence with anti- $\beta$ III tubulin antibody for determination of neurite outgrowth by HCA (c, d), as described in "Materials and methods". Data are expressed as mean \pm SEM for at least 3 independent experiments. Asterisks indicate the level of statistical significance of differences $(* * * P<0.001, * * P<0.01, * P<0.05)$

\section{Statistical analysis}

Quantitative data are expressed as mean \pm SEM for a minimum of 3 independent experiments. Statistical significance of differences was determined by one-way or two-way ANOVA (as appropriate), followed by Tukey's post hoc test, using GraphPad Prism ${ }^{\circledR}$ software. A significant difference was assumed if $P<0.05$.

\section{Results}

\section{Effects of PSP on N2a cell viability and neurite outgrowth}

The ability of PSP to affect the viability and differentiation of N2a cells was monitored by Trypan Blue exclusion and HCA, respectively. Over the concentration range tested 


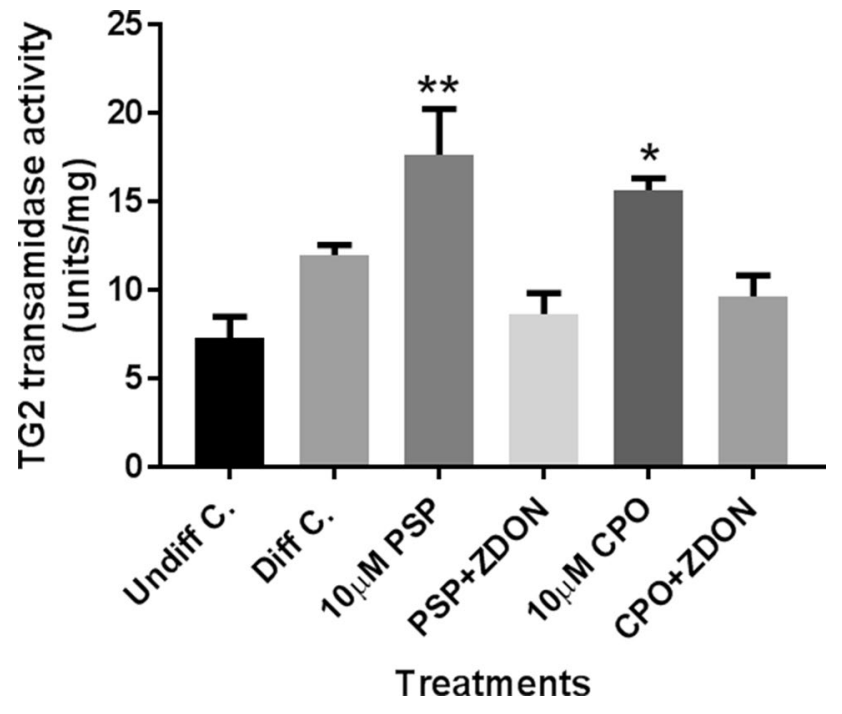

Fig. 2 Effects of PSP and CPO on TG2 activity in cell lysates from differentiating N2a cells. Mitotic N2a cells were pre-treated in the absence or presence of the TG2 inhibitor Z-DON $(100 \mu \mathrm{M})$ for $1 \mathrm{~h}$ and then subjected to differentiation for $24 \mathrm{~h}$ in serum-free medium containing $0.3 \mathrm{mM}$ dibutyryl cAMP, in the absence or presence of PSP or CPO (both at $10 \mu \mathrm{M}$ ). Cell lysates were subjected to biotincadaverine incorporation assays, as described in "Materials and methods". Data points represent the mean \pm SEM of TG2 specific activity from 3 independent experiments. Data analysis was performed using one-way ANOVA with the Tukey post hoc test. Asterisks indicate the level of statistical significance of differences from the control $(* * * P<0.001, * * P<0.01, * P<0.05)$

(1-10 $\mu \mathrm{M})$ PSP had no statistically significant effect on the exclusion of Trypan Blue (Fig. 1a). It did, however, induce a concentration-dependent reduction in average neurite length, as indicated by HCA of differentiating cell monolayers stained by indirect immunofluorescence using anti- $\beta$ III tubulin antibody (Fig. 1b). Similar trends were observed in the case of treatment with CPO (Fig. 1c, d).

\section{Effect of PSP on TG2 activity in differentiating N2a cells}

For initial studies of the ability of PSP to disrupt TG2 activity, lysates prepared from N2a cells induced to differentiate in the presence and absence of $10 \mu \mathrm{M}$ PSP or CPO in serum-free medium containing dibutyryl cAMP, were subjected to assays for the incorporation of biotin cadaverine, which acts as the acyl-acceptor for TG2. The data shown in Fig. 2 show a slight increase in TG2 activity on cell differentiation and a statistically significant increase in activity on differentiation in the presence of PSP compared to control undifferentiated cells. In the case of PSP-treated cells that were co-treated with the TG2 inhibitor ZDON there was a significant decrease in amine incorporation
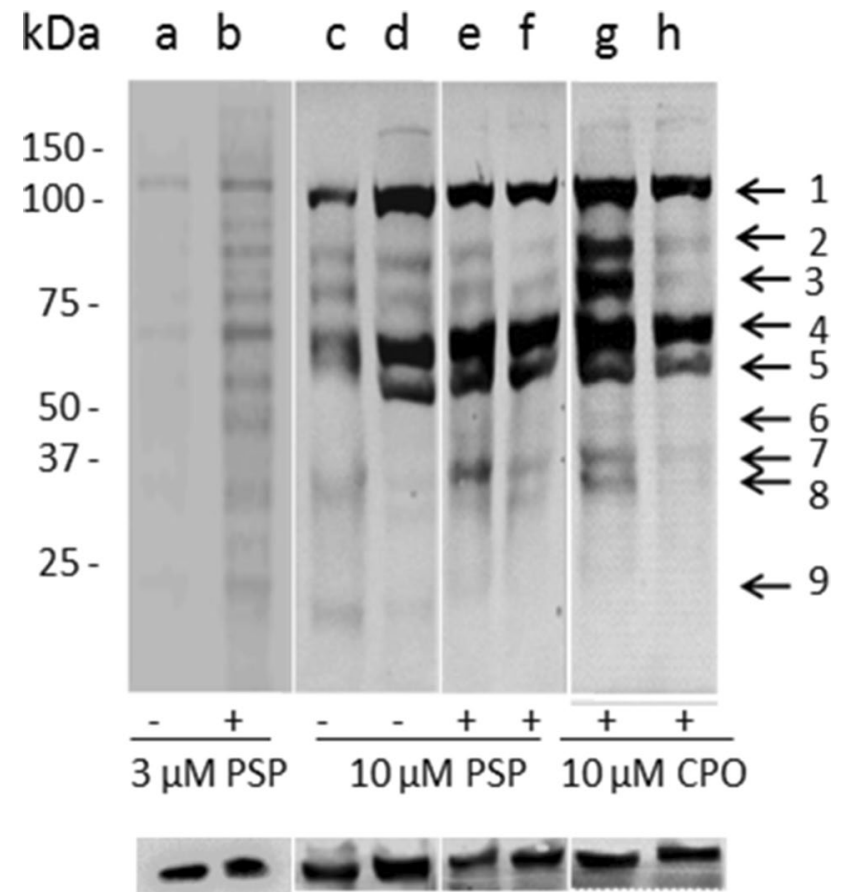

Fig. 3 Western blot analysis of the effects of PSP on in situ TG activity in differentiating N2a cells. Cells were pre-incubated for $1 \mathrm{~h}$ with $(\mathbf{f}, \mathbf{h})$ or without $(\mathbf{a}-\mathbf{e}$ and $\mathbf{g})$ the TG2 inhibitor Z-DON $(100 \mu \mathrm{M})$ before the induction of cell differentiation for $24 \mathrm{~h}$ in the absence and presence of $3 \mu \mathrm{M}(\mathbf{a}, \mathbf{b})$ or $10 \mu \mathrm{M}$ PSP and CPO $(\mathbf{c}-\mathbf{h})$. Well (c) contained non-differentiated (i.e., mitotic) cell lysate protein. For the last $4 \mathrm{~h}$ of treatments, $1 \mathrm{mM}$ biotin-X-cadaverine was added. The total protein extract was resolved by SDS-PAGE (40 $\mu$ g per lane) and transferred onto nitrocellulose membranes. Biotin-cadaverine labelled proteins were detected using ExtrAvidin ${ }^{\circledR}$-HRP. Samples were subsequently analysed on a separate blot using an anti-GAPDH antibody as a control for protein loading (lower panel). The arrows point to biotin-ExtrAvidin-labelled proteins that show increased labelling following exposure to PSP or CPO that was attenuated by pre-treatment with ZDON

compared to cells treated with PSP alone. Similar results were obtained for CPO exposure.

It was then of interest to determine whether the same trend would be observed for TG2 activity in situ. As shown in Fig. 3, there was an apparent increase in the level of biotin-X-cadaverine incorporation into selected protein bands on Western blots of lysates prepared from $\mathrm{N} 2 \mathrm{a}$ cells induced to differentiate in the absence and presence of PSP $(3,10 \mu \mathrm{M})$ compared to non-OP-treated control cells, with molecular weights ranging from $\sim 25$ to $150 \mathrm{kDa}$, as indicated by horizontal arrows (Fig. 3). The corresponding bands had labelling similar to that of controls when cells were co-treated with the TG2 inhibitor ZDON $(100 \mu M)$. Similar results were observed for lysates prepared from differentiating N2a cells exposed to $10 \mu \mathrm{M}$ CPO (Fig. 3). As shown in Fig. 4, densitometric quantification of whole lanes showed a statistically significant 


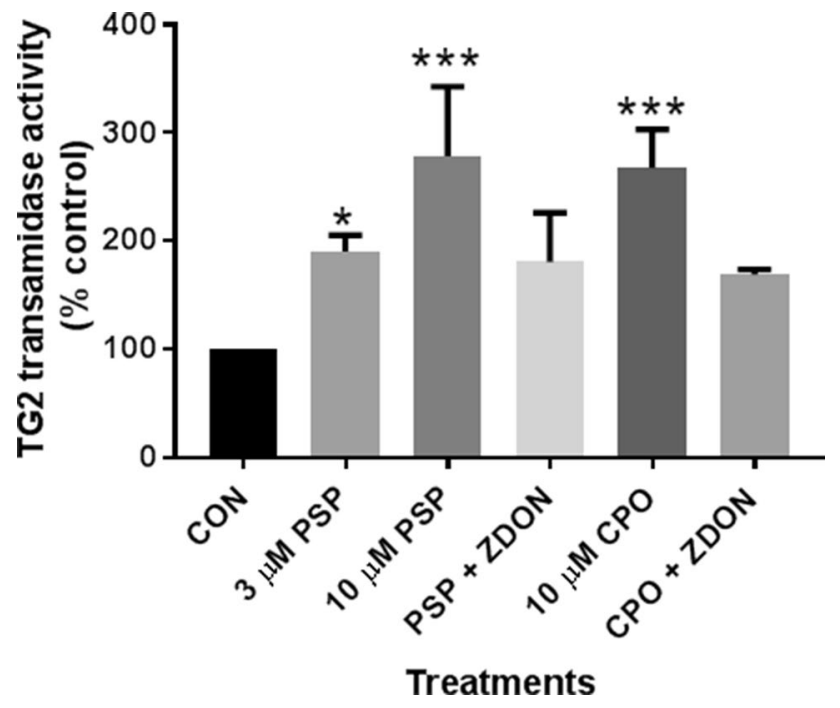

Fig. 4 Densitometric analysis of biotin-cadaverine incorporation into proteins detected on Western blots of cell lysates from differentiating N2a cells. Following in situ labelling of differentiating N2a cells with biotin-X-cadaverine, Western blots of cell lysates (shown in Fig. 3) were probed with ExtrAvidin ${ }^{\circledR}$-HRP, as described in "Materials and methods". Densitometric analysis of each lane (total labelled protein) was carried out using GelQuant software and the data are expressed as the percentage of basal TG2 substrate protein levels \pm SEM after GAPDH normalization. Data analysis was performed using one-way ANOVA with the Tukey post hoc test. Asterisks indicate the level of statistical significance of differences from the differentiating cell control $* * * P<0.001, * * P<0.01, * P<0.05$

increase in overall band intensity on the developed blots from lysates of OP-treated cells compared to the non-OPtreated controls. These biotin-cadaverine labelled proteins showed reduced staining on western blots of lysates from cells that were incubated in the presence of both OP and the TG2 inhibitor ZDON, the activity returning to basal levels. In situ labelling was also monitored by fluorescence microscopy using FITC-labelled ExtrAvidin ${ }^{\mathrm{TM}}$, for which a qualitatively similar pattern of staining was observed, as shown in Fig. 5.

\section{Direct effects of organophosphates on human and mouse recombinant TG 2 activity}

To study the possibility of a direct effect of PSP on TG2 activity, human and mouse recombinant TG2 were assayed in the absence and presence of $10 \mu \mathrm{M}$ PSP or CPO using the biotin-cadaverine incorporation assay (Fig. 6). The data obtained indicated a significant OP-induced increase in recombinant TG2 activity. All activity was blocked by co-treatment with $100 \mu \mathrm{M}$ ZDON. To determine whether this reflected covalent adduct formation between TG2 and PSP, recombinant TG2 was incubated with a dansylamine-labelled analogue of PSP, which had previously been used to identify PSP adducts in cardiomyocytelike cells (Felamban et al. 2015). The gel images in Fig. 7 show that both human and mouse recombinant TG2 incubated with dansylamine-labelled PSP were detectable as fluorescent bands after separation by SDS-PAGE.

\section{Effects of PSP on the intracellular distribution TG2 and $\alpha$-tubulin}

It was of further interest to determine whether exposure to OPs affected the intracellular distribution of TG2. As shown in Fig. 8a, b, immunofluorescence staining with a monoclonal antibody that recognises $\alpha$-tubulin revealed a similar staining pattern with respect to relative intensity of neurite/ cell body staining in control and PSP-treated cells. By contrast the relative intensity of staining of neurite: cell body staining with two different anti-TG2 antibodies was higher in PSP-treated cells than in the controls (Fig. 8c-f).

\section{Identification of protein substrates of TG2-mediated transamidase activity}

Prior to identification of TG2 substrates, biotin-cadaverine labelled proteins were enriched using CaptAvidin ${ }^{\mathrm{TM}}$ agarose (Almami et al. 2014). Biotin-cadaverine labelled TG2 substrate proteins captured by CaptAvidin ${ }^{\mathrm{TM}}$ beads were separated by SDS-PAGE and proteins revealed by staining with Coomassie Brilliant Blue. The protein bands corresponding in molecular weight to those showing activation and inhibition of TG2-mediated biotincadaverine incorporation activity were excised from gels (arrows in Fig. 3). The proteins were then extracted from gel pieces and subjected to trypsin digestion after reduction and alkylation, as described in "Materials and methods". Digested samples were then analysed by LC-MS/ MS, as a result of which multiple proteins were identified within each Coomassie-stained band. Proteins with at least 3 peptide matches following ProteinPilot searching against the $\mathrm{SwissProt}$ mouse database are listed in Table 1. Proteins that were identified as potential TG2 substrates ranged in molecular weight from approximately 30 to $150 \mathrm{kDa}$. These included cytoskeletal proteins (e.g., vimentin, peripherin, lamin B1, tubulin and actin), chaperone and folding proteins (e.g., HSPs 60,70 and 90 ), $\mathrm{Ca}^{2+}$ and phospholipid binding proteins (e.g., matrin 3), mitochondrial proteins (e.g., MICOS complex subunit mic60, Cytochrome b-c1 complex subunit 2 and ATP-citrate synthase), in addition to several other proteins involved in the regulation of protein synthesis (e.g., elongation factors 1 -alpha 1, 1-alpha 21 -gamma and various ribosomal proteins), gene expression (e.g., various isoforms of histone H1), and metabolism (e.g., GAPDH). 
of bands of interest in CaptAvidin-captured proteins separated by SDS-PAGE allowed the identification of a number of known and novel potential substrates, none of which had been previously identified as substrates in N2a cells. These could be grouped into several categories based on function, including cytoskeletal proteins, chaperones and proteins involved in gene expression and/or protein synthesis.

For example, $78 \mathrm{kDa}$ glucose-regulated protein Hspa5 chaperone is a quality control protein the endoplasmic reticulum lumen, involved in the correct folding of proteins and degradation of misfolded proteins (Weng et al 2011). It also plays a key role in neurological disorders, acting as a stress sensor, and in embryonic development of the central nervous system (Zhang et al. 2007). It also has an essential role in protection from neuronal apoptosis (Wang et al. 2010).
Indeed, a proteomic analysis study conducted by our group before has demonstrated upregulation of $78 \mathrm{kDa}$ glucoseregulated protein in $\mathrm{N} 2 \mathrm{a}$ neuroblastoma cells following exposure to the organophosphorous compound diazinon (Harris et al. 2009b). This protein has been already identified as a TG2 substrate in H9c2 cardiomyocyte-like cells (Almami 2014). Whether its modification by TG2- mediated transamidation enhances or attenuates its activity remains to be determined.

Interestingly, an IgE-binding protein was identified in CaptAvidin-captured proteins as a novel protein substrate for TG2. This may reflect the fact IgE receptors have been detected on the surface of neuronal cells and are thought to be involved in a variety of inflammatory responses of sensory neurones to IgE-antigen complexes (Andoh and

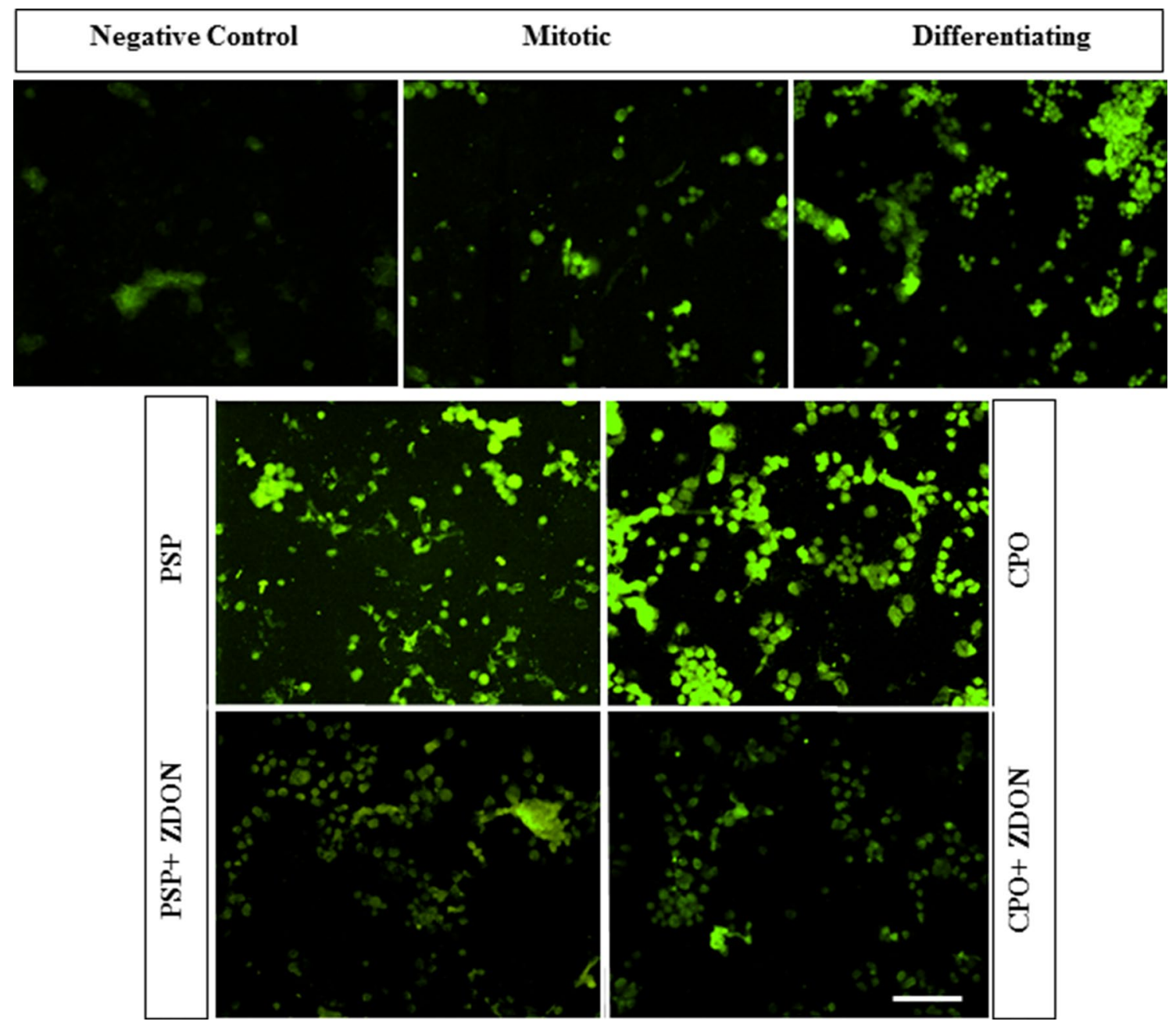

Fig. 5 Measurement of the effects of organophosphates on in situ TG2 activity in differentiating N2a cells using Extravidin ${ }^{\circledR}$-FITC. Cells were seeded in chamber slides and incubated with biotin-Xcadaverine after treatment with or without $10 \mu \mathrm{M}$ PSP, $10 \mu \mathrm{M}$ CPO and ZDON, followed by Extravidin ${ }^{\circledR}$-FITC (green), as described in "Materials and methods". Shown are typical images from a representative experiment (one of three). Images show typical fields of
N2a cells, treated for $1 \mathrm{~h}$ with or without the TG2 inhibitor Z-DON $(100 \mu \mathrm{M})$ before the induction of differentaition in the presence and absence of $10 \mu \mathrm{M}$ PSP or CPO for $24 \mathrm{~h}$. For the last $4 \mathrm{~h}$ of treatments, $1 \mathrm{mM}$ biotin-X-cadaverine was added, except for one set of untreated cells used as a negative control with no biotin-cadaverine. Nuclei were stained with DAPI (blue). The original magnification of the images was $20 \times$. Bar represents $200 \mu \mathrm{m}$ 


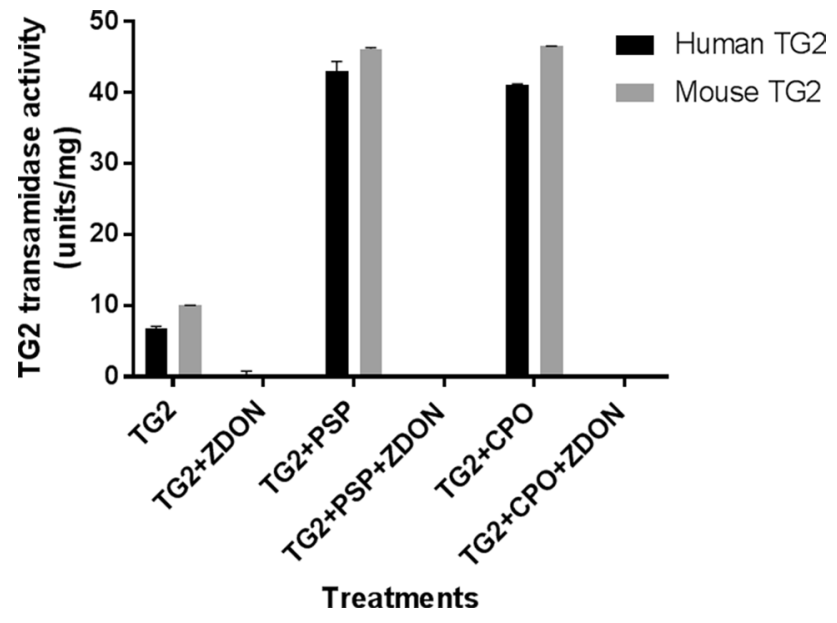

Fig. 6 Direct effects of organophosphates on recombinant TG 2 activity. TG2-mediated transamidase activity of human and mouse recombinant TG2 was determined using the biotin-cadaverine incorporation assay as described in "Materials and methods". Data points represent the mean specific activity \pm SEM. Data analysis was performed using two-way ANOVA followed by the Dunnett's post hoc comparison test, as indicated. Asterisks indicate the statistical significance of differences $(* * * P<0.001, * * P<0.01, * P<0.05)$

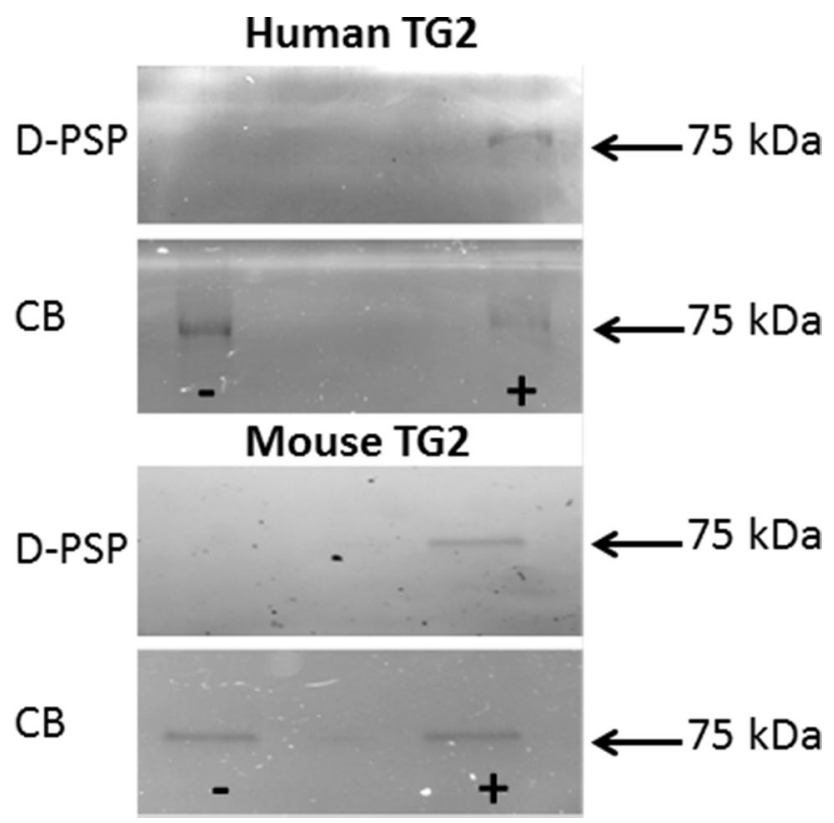

Fig. 7 Formation of covalent adducts between TG2 and PSP. Covalent labelling of human or mouse recombinant TG2 with dansylamine-labelled PSP (D-PSP) was detected in a fluorescence imager after SDS-PAGE (upper panels) and Instant Blue staining (CB) of total protein in the same samples (lower panels), as indicated

Kuraishi 2004; Van der Klejj et al. 2010; Liu et al. 2017). This finding is consistent with the possibility that TG2mediated amine incorporation may be involved in the modulation of such processes.
Several of the other substrates identified in CaptAvidincaptured protein extracts are involved in the regulation of protein synthesis and gene expression, including a number of histones, elongation factors and RNA-binding proteins, etc. Similar types of proteins have been identified as TG2 substrates in studies of adenosine receptor stimulation in cardiomyocyte-like cells (Almami et al. 2014; Vyas et al. 2016,2017 ). The nuclear matrix protein matrin 3 , on the other hand, is a potentially novel TG2 substrate; it is modulated by $\mathrm{Ca}^{2+} / \mathrm{calmodulin}$ binding, cleaved by caspases and is involved in the control of mRNA stability (Valencia et al. 2007; Salton et al. 2011). Mutations in the matrin 3 gene are linked with familial forms of amyotrophic lateral sclerosis, suggesting an important role in neuroprotection (Johnson et al. 2014). It may be that TG2-mediated amine incorporation can modulate the activity of these groups of proteins during OP-exposure and that this is partly responsible for changes observed in gene expression and protein levels in previous studies on developmental neurotoxicity in brain and cultured cell models (Garcia et al. 2001; Qiao et al. 2001; Howard et al. 2005; Sachana et al. 2001, 2008; Yang et al. 2008; Flaskos et al. 2011; Grandjean and Landrigan 2014; Lee et al. 2015).

Actin and tubulin are the core components of microfilaments and microtubules, respectively, and are significantly expressed in nerve tissue and differentiated neuroblastoma cell lines (Oh et al. 2006). Two isoforms of both actin and tubulin have been identified as TG2 substrates by us previously, following stimulation of adenosine receptors in H9c2 cells (Vyas et al. 2016, 2017) and are well established TG2 substrates. A covalent interaction of $\mathrm{CPO}$ with tubulin beta-5 was also observed in extracts from mouse brain (Jiang et al. 2010) suggesting that it is an important target in OP-induced delayed neurotoxicity. The beta-5 tubulin isoform was previously identified as a substrate for TG2 in cardiomyocyte-like cells (Vyas et al. 2016, 2017), although other isoforms of both alpha and beta tubulin are also recognised substrates on the online database (https://genomics.dote.hu/wiki/index .php/). The identification of vimentin and peripherin as substrates suggests that proteins in all 3 cytoskeleton networks (i.e., microtubules, microfilaments and intermediate filaments) are targeted by TG2 in OP-treated cells.

Upregulation of Stip1 is correlated with neuroprotection during ischemic insult; this protein is released from astrocytes and it causes increases in intracellular $\mathrm{Ca}^{2+}$ levels by activation of the alpha-7-nicotinic ACh receptor (Beraldo et al. 2013). Stip1, along with HSP 90-beta, stress-70 cognate $71 \mathrm{kDa}$ and HSP 60 are chaperone proteins involved in cytoprotection, modulation of protein folding and transport, and have been shown to be up-regulated after a toxic insult by the OP nerve agent sarin in mouse brain (Chaubey et al. 2017). The level of Stip1 also increased in the brain following ischaemia, inducing neuroprotective signals that rescue 
Fig. 8 Effects of PSP on the distribution of TG2 and $\alpha$-tubulin in differentiating $\mathrm{N} 2 \mathrm{a}$ cells. $\mathrm{N} 2 \mathrm{a}$ cells were induced to differentiate in chamber slides for $24 \mathrm{~h}$ in the presence and absence of $3 \mu \mathrm{M}$ PSP. Cells were then fixed and permeabilised as detailed in "Materials and methods". Fixed monolayers were probed with monoclonal anti- $\alpha$-tubulin (clone B512) (a, b), and two monoclonal antibodies to TG2: clones ID10 (c, d) and CUB7402 (e, f). Scale bar represents $20 \mu \mathrm{m}$. Arrows indicate typical neurites
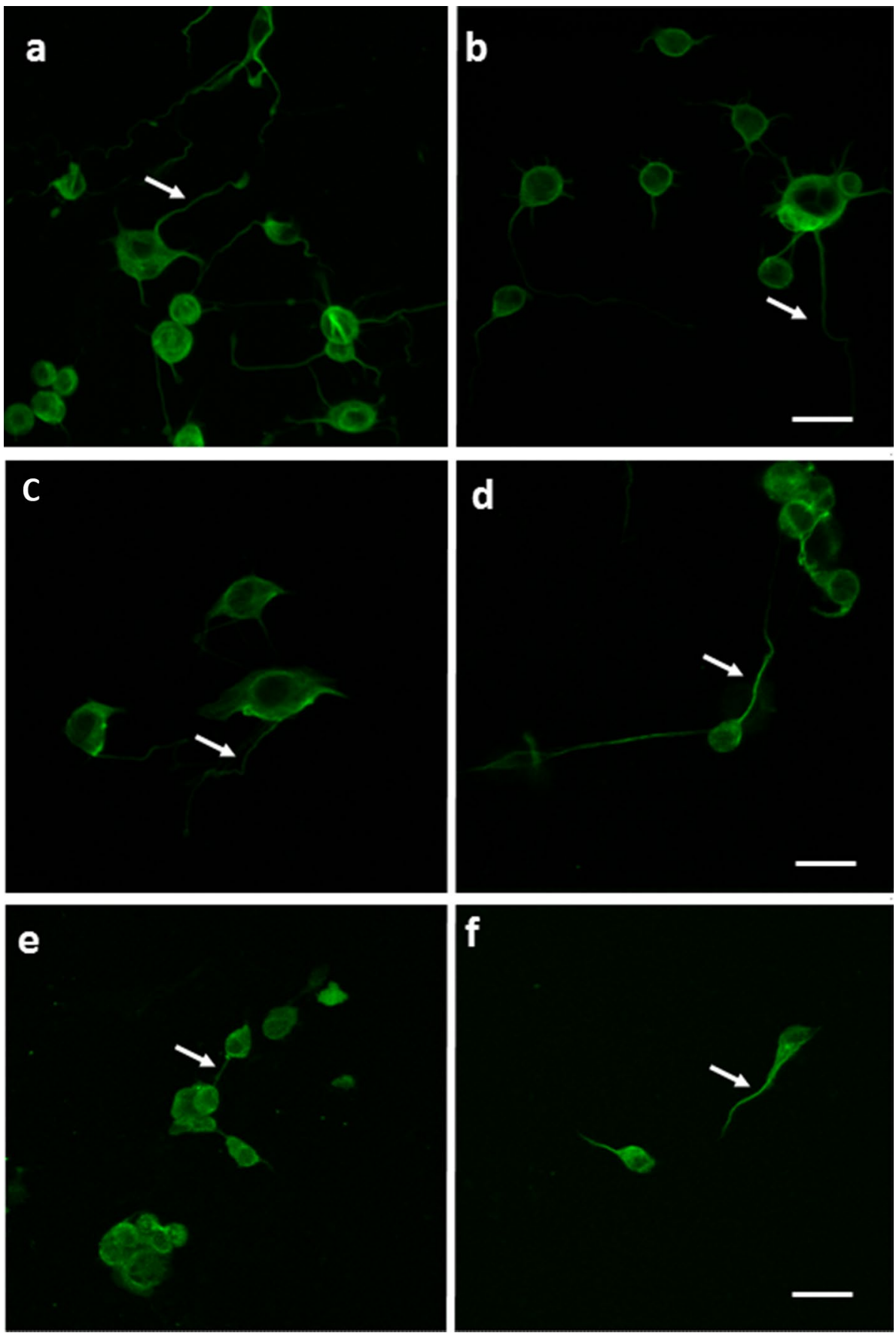

According to the TRANSDAB database (https://genom ics.dote.hu/wiki/index.php/), some of the identified proteins were already reported as TG2 substrates (Csôsz et al. 2009), but they have not as yet been identified as such in differentiating $\mathrm{N} 2$ a cells though we have identified some as TG2 substrates in $\mathrm{H} 9 \mathrm{c} 2$ cardiomyocyte-like cells. Those previously identified by our group include heat shock protein HSP 90-beta, Stress-70 cognate $71 \mathrm{kDa}$ and HSP $60 \mathrm{kDa}$, isoforms of actin and tubulin, myosin-9, elongation factor 1 -alpha 1 , tropomyosin, vimentin, histones and heterogeneous nuclear ribonucleoprotein A1 (Almami et al. 2014; Vyas et al. 2016, 2017).

\section{Discussion}

The results presented in this study show that sub-lethal neurite inhibitory concentrations of PSP, an OP associated with the induction of OPIDN, induced elevated levels of TG2-mediated transamidase activity, as determined 
Table 1 Identification of TG 2 substrates by mass spectrometry

\begin{tabular}{|c|c|c|c|c|c|}
\hline Band & $\%$ Coverage & Accession number (s) & $\begin{array}{l}\text { Proteins identified as potential TG2 } \\
\text { substrates }\end{array}$ & Peptide matches & Approx mass (Da) \\
\hline \multirow[t]{3}{*}{1} & 6 & Q8VEK3 & $\begin{array}{l}\text { Heterogeneous nuclear ribonucleopro- } \\
\text { tein U }\end{array}$ & 6 & 87,918 \\
\hline & 4 & Q8K310 & Matrin-3 & 3 & 94,630 \\
\hline & 2.6 & Q91V92 & ATP-citrate synthase & 3 & 119,728 \\
\hline 2 & 18.4 & P58252 & Elongation factor 2 & 14 & 95,314 \\
\hline \multirow[t]{2}{*}{3} & 20.3 & P11499 & Heat shock protein HSP 90-beta & 15 & 83,281 \\
\hline & 7 & Q8CAQ8 & MICOS complex subunit Mic60 & 5 & 83,900 \\
\hline \multirow[t]{8}{*}{4} & 30.9 & P38647 & $\begin{array}{l}\text { Stress-70 protein, mitochondrial } \\
\text { (GRP75) }\end{array}$ & 26 & 73,680 \\
\hline & 31.7 & P63017 & Heat shock cognate $71 \mathrm{kDa}$ protein & 25 & 70,871 \\
\hline & 13.6 & Q9D0E1 & $\begin{array}{l}\text { Heterogeneous nuclear ribonucleopro- } \\
\text { tein M }\end{array}$ & 10 & 77,649 \\
\hline & 16.5 & P03975 & IgE-binding protein & 8 & 62,747 \\
\hline & 13.3 & P14733 & Lamin B1 & 8 & 66,786 \\
\hline & 11 & P20029 & $78 \mathrm{kDa}$ glucose-regulated protein & 6 & 72,422 \\
\hline & 6.7 & Q99MN1 & Lysine-tRNA ligase & 4 & 67,840 \\
\hline & 4.5 & P26041 & Moesin & 3 & 67,767 \\
\hline \multirow[t]{3}{*}{5} & 27.2 & P63038 & $\begin{array}{l}60 \mathrm{kDa} \text { heat shock protein, mitochon- } \\
\text { drial }\end{array}$ & 16 & 60,955 \\
\hline & 15.7 & Q60864 & Stress-induced-phosphoprotein 1 & 8 & 62,582 \\
\hline & $15.1,10.2,9.2,8.6,7.4,6.9$ & $\begin{array}{r}\text { P61979, Q8R081, } \\
\text { P02535, 61,414, } \\
\text { P19001, P08730 }\end{array}$ & $\begin{array}{l}\text { Heterogeneous nuclear ribonucleopro- } \\
\text { teins } \mathrm{K} \text { and L }\end{array}$ & 7-Mar & $44,542-63,964$ \\
\hline \multirow[t]{9}{*}{6} & 25.7 & P99024 & Tubulin beta- 5 chain & 13 & 49,671 \\
\hline & 22.8 & P20152 & Vimentin & 10 & 53,688 \\
\hline & 10.5 & Q9D8E6 & 60 S ribosomal protein $\mathrm{L} 4$ & 6 & 47,154 \\
\hline & $10.5,10.4,10.4,8.3,8.7$ & $\begin{array}{l}\text { P68373, P68369, } \\
\text { P05213, P68368, and } \\
\text { P05214 }\end{array}$ & $\begin{array}{l}\text { Tubulin alpha-1C, } 1 \mathrm{~A}, 1 \mathrm{~B}, 4 \mathrm{~A} \text { and } 3 \\
\text { chains }\end{array}$ & $6,6,6,5,4$ & $\begin{array}{l}49,909 / 50,136 / 50,152 \\
/ 49,924 / 49,960\end{array}$ \\
\hline & $11.5,9.0$ & P56480, Q03265 & $\begin{array}{l}\text { ATP synthase subunits } \beta \text { and } \alpha \text {, mito- } \\
\text { chondrial }\end{array}$ & 5,4 & $56,300 / 59,753$ \\
\hline & 5.4 & P09405 & Nucleolin & 4 & 76,723 \\
\hline & 7.5 & P03975 & IgE-binding protein & 4 & 62,747 \\
\hline & 8.6 & Q922R8 & Protein disulphide-isomerase A6 & 3 & 48,100 \\
\hline & 6.1 & P15331 & Peripherin & 3 & 54,268 \\
\hline \multirow[t]{6}{*}{7} & 38.3 & P17182 & Alpha-enolase & 18 & 47,141 \\
\hline & 15.8 & P03975 & IgE-binding protein & 7 & 62,747 \\
\hline & 14.2 & Q9D8N0 & Elongation factor 1-gamma & 5 & 50,061 \\
\hline & 8.8 & P20152 & Vimentin & 4 & 53,688 \\
\hline & $11.5,11.5$ & P62631, P10126 & $\begin{array}{l}\text { Elongation factor 1-alpha } 2 \text { and } \\
\text { 1-alpha-1 }\end{array}$ & 4,4 & $50,454 / 50,114$ \\
\hline & $8.2,8.3$ & Q9ERD7, P99024 & Tubulin beta- 3 and 5 chains & 3,3 & $50,419 / 49,671$ \\
\hline
\end{tabular}


Table 1 (continued)

\begin{tabular}{|c|c|c|c|c|c|}
\hline Band & $\%$ Coverage & Accession number (s) & $\begin{array}{l}\text { Proteins identified as potential TG2 } \\
\text { substrates }\end{array}$ & Peptide matches & Approx mass (Da) \\
\hline \multirow[t]{9}{*}{8} & 22.8 & P20152 & Vimentin & 10 & 53,688 \\
\hline & 17.8 & P03975 & IgE-binding protein & 8 & 62,747 \\
\hline & $19.2,19.2$ & P63260, P60710 & Actin, cytoplasmic 1 and 2 & 7,7 & $41,793 / 41,737$ \\
\hline & 17.6 & Q8VE37 & $\begin{array}{l}\text { Regulator of chromosome condensa- } \\
\text { tion }\end{array}$ & 6 & 44,931 \\
\hline & 11.6 & Q91VM5 & $\begin{array}{l}\text { RNA binding motif protein, } \mathrm{X} \text {-linked- } \\
\text { like-1 }\end{array}$ & 4 & 42,162 \\
\hline & 11.5 & Q9WV02 & $\begin{array}{l}\text { RNA-binding motif protein, } \mathrm{X} \text { chro- } \\
\text { mosome }\end{array}$ & 4 & 42,301 \\
\hline & 8.9 & Q9D8N0 & Elongation factor 1-gamma & 4 & 50,061 \\
\hline & 11.5 & Q9DB77 & $\begin{array}{l}\text { Cytochrome b-c1 complex subunit } 2 \text {, } \\
\text { mitochondrial }\end{array}$ & 5 & 48,235 \\
\hline & 8.1 & O35685 & Nuclear migration protein nudC & 3 & 38,358 \\
\hline \multirow[t]{7}{*}{9} & 33.9 & P16858 & $\begin{array}{l}\text { Glyceraldehyde-3-phosphate dehydro- } \\
\text { genase }\end{array}$ & 18 & 35,810 \\
\hline & $23.1,18.4,30.6$ & P43277, P15864, P43274 & Histones H1.3, H1.2 and H1.4 & $8,7,8$ & $22,100 / 21,267 / 21,977$ \\
\hline & 29.3 & P14148 & 60 S ribosomal protein $\mathrm{L} 7$ & 8 & 31,420 \\
\hline & 28.3 & P43276 & Histone $\mathrm{H} 1.5$ & 7 & 22,576 \\
\hline & 20.8 & P97351 & $40 \mathrm{~S}$ ribosomal protein $\mathrm{S} 3 \mathrm{a}$ & 5 & 29,885 \\
\hline & 13.5 & P70372 & ELAV-like protein 1 & 4 & 36,169 \\
\hline & 10.2 & P25444 & 40S ribosomal protein $\mathrm{S} 2$ & 3 & 31,231 \\
\hline
\end{tabular}

Biotin-cadaverine labelled TG2 substrate proteins captured by captavidin beads were separated by SDS-PAGE and the 9 main bands showing increased TG2-mediated labelling were excised and analysed by mass spectrometry. Data shown are for abundant proteins showing a minimum of 3 peptide matches determined with $95 \%$ confidence levels. Molecular weight (MW) is also indicated in Da, according to values published on UniProt. As discussed, some of these are potentially novel TG2 substrates not currently listed on the TRANSDAB database (https://genomics. dote.hu/wiki/index.php/) of Csôsz et al. (2009) or identified as potential substrates in our own previous work (Almami et al. 2014; Vyas et al. 2016, 2017)

by assays performed on cell lysates prepared following treatment and by in situ labelling with the membrane permeable substrate biotin-X-cadaverine. The fact that OPinduced increases in transamidase activity in differentiated cells were significantly attenuated by ZDON provided further conformation that TG2 was involved.

The possibility that this might be due to a direct effect of PSP on TG2 was confirmed in assays using mouse and human recombinant $\mathrm{TG} 2$, which also showed elevated levels of biotin-cadaverine incorporation in the presence of PSP. This suggested that TG2 could be a novel PSP binding protein, which was subsequently confirmed by the observation of a fluorescent TG2 band following incubation with dansylamine-labelled PSP and separation by SDS-PAGE, indicating the formation of a novel covalent adduct with both mouse and human recombinant TG2.

The fact that similar effects on TG2 activity were observed for the oxon metabolite of the organophosphorothioate CPF (i.e., CPO), suggests that other OPs may also interact directly with TG2. Given the known importance of TG2 in neurite outgrowth (Perry et al. 1995; Mahoney et al. 2000; Tucholski et al. 2001, 2003) an important morphological determinant of neuronal cell differentiation during development and also in nerve regeneration, and the observation of TG2 upregulation in neurodegenerative diseases (Kim et al. 2002; Grosso and Mouradian 2012), our findings suggests that TG2 represents a new and highly relevant non-cholinesterase protein target for OP-binding. It is possible that OP adduction induces the acquisition of a toxic property in TG2, such as that proposed for NTE in OPIDN (Glynn 2000). Alternatively, the changes observed may reflect a protective effect of TG2 upregulation. Indeed, the enrichment of anti-TG2 immunofluorescence staining in surviving neurites in PSP-treated cells, compared to those of control N2a cells, is indicative of a redistribution of TG2, which is consistent with this possibility.

To further investigate the consequences of TG2 upregulation, it was of interest to identify the potential substrates of TG2 in OP-induced inhibition of neurite outgrowth. Analysis 
the cell from apoptosis (Beraldo et al. 2015). It would be of value to carry out further work to determine the effects of increased amine incorporation on the biochemical properties and functions of this and the other proteins identified as potential substrates of TG2 in OP-treated differentiating N2a cells.

In conclusion, under conditions that cause inhibition of neurite outgrowth, OPs are capable of binding covalently to TG2 and activating TG2-mediated transamidase activity, targeting a number of proteins essential for the integrity of neurites and others involved in the regulation of gene expression, protein synthesis and protein folding.

It could be that $\mathrm{OP}$ adduct formation reduces the $\mathrm{Ca}^{2+}$ requirement for TG2 activation in situ and/or that it binds to a regulatory domain that exerts an allosteric effect on the active site. Indeed, characterisation of the OP-binding sites on TG2 and their role in TG2 modulation will help to determine the mechanism involved. Further work will also help to determine the precise role of TG2 and its modified protein substrate in OP-induced inhibition of neurite outgrowth.

\section{Compliance with ethical standards}

Conflict of interest The authors declare that they have no conflicts of interest.

Open Access This article is licensed under a Creative Commons Attribution 4.0 International License, which permits use, sharing, adaptation, distribution and reproduction in any medium or format, as long as you give appropriate credit to the original author(s) and the source, provide a link to the Creative Commons licence, and indicate if changes were made. The images or other third party material in this article are included in the article's Creative Commons licence, unless indicated otherwise in a credit line to the material. If material is not included in the article's Creative Commons licence and your intended use is not permitted by statutory regulation or exceeds the permitted use, you will need to obtain permission directly from the copyright holder. To view a copy of this licence, visit http://creativecommons.org/licenses/by/4.0/.

\section{References}

Abou Donia MB, Lapadula DM (1990) Mechanisms of organophosphorus ester induced delayed neurotoxicity: type I and II. Ann Rev Pharmacol Toxicol 30:405-440

Aldridge WN (1954) Tricresyl phosphates and cholinesterase. Biochem J 56:185-189

Aldiss P, Lewis JE, Boocock DJ, Miles AK, Bloor I, Ebling FJP, Budge H, Symonds ME (2019) Interscapular and perivascular brown adipose tissue respond differently to a short-term fat diet. Nutrients 11(5):1065

Aldubayan MA, Almami IS, Benslimane FM, Alsonosi AM, Forsythe SJ (2017) Comparative outer membrane protein analysis of high and low-invasive strains of Cronobacter malonaticus. Front Microbiol 8:2268
Almami I (2014). Modulation of transglutaminase 2 activity in H9c2 cells by protein kinase $\mathrm{A}$ and protein kinase $\mathrm{C}$ signalling. $\mathrm{PhD}$ thesis, Nottingham Trent University, UK.'

Almami I, Dickenson JM, Hargreaves AJ, Bonner PLR (2014) Modulation of transglutaminase 2 activity in $\mathrm{H} 9 \mathrm{c} 2$ cells by $\mathrm{PKC}$ and PKA signalling: a role for transglutaminase 2 in cytoprotection. Brit J Pharmacol 171(16):3946-3960

Andoh T, Kuraishi Y (2004) Expression of Fc epsilon receptor 1 on primary sensory neurons in mice. NeuroReport 15(13):2029-2031

Beraldo FH, Ostapchenko VG, Xu JZ, Guglielmo GM, Fan J, Nicholls PJ, Caron MG, Prado VF, Prado MAM (2015) Mechanisms of neuroprotection against ischemic insult by stress-inducible phosphoprotein-1/prion protein complex. J Neurochem 145(1):68-79

Beraldo FH, Soares IN, Goncalves DF, Fan J, Thomas AA, Santos GG, Mohammed AH, Roffé M, Calder MD, Nikolova S, Hajj GN, Guimarares AL, Massensini AR, Welch I, Betts DH, Gros R, Drangova M, Watson AJ, Bartha R, Prado VF, Martins VR, Prado MAM (2013) Stress-inducible phosphoprotein 1 has unique chaperone activity during development and regulates cellular response to ischemia via the prion protein. FASEB J 27(9):3594-3607

Bergamini CM, Collighan RJ, Wang Z, Griffin M (2011) Structure and regulation of type 2 transglutaminase in relation to its physiological functions and pathological roles. Adv Enzymol Relat Areas Mol Biol 78:1-46

Bishop EL, Stewart HC (1930) Incidence of partial paralysis. Am J Public Health 20:1307-1312

Chambers JE, Levi PE (1992) Organophosphates. Chemistry, fate and effects. Elsevier, Amsterdam

Chaubey K, Alam SI, Nagar DP, Waghmare CK, Pant SC, Singh L, Srivastava N, Bhattacharya BK (2017) Proteome profile of different rat brain regions after sarin intoxication. Toxicol Sci 160(1):136-149

Cooper GM, Hausman RE (2004) The cell: molecular approach. Medicinska Naklada, Zagreb

Crumpton TL, Seidler FJ, Slotkin TA (2000) Is oxidative stress involved in the developmental neurotoxicity of chlorpyrifos? Dev Brain Res 121(2):189-195

Csôsz É, Meskó B, Fésüs L (2009) Transdab wiki: the interactive transglutaminase substrate database on web 2.0 surface. Amino Acids 36(4):615-617

Duman RS, Malberg J, Nakagawa S, D'Sa C (2000) Neuronal plasticity and survival in mood disorders. Biol Psychiat 48(8):732-739

Estevan C, Fuster E, del Rio E, Pamies D, Vilanova E, Sogorb MA (2014) Organphosphorus pesticide chlorpyrifos and its metabolites alter the expression of biomarker genes of differentiation in in D3 mouse embryonic stem cells in a comparable way to other model neurodevelopmental toxicants. Chem Res Toxicol 27(9):1487-1495

Felemban SG, Garner AC, Smida FA, Boocock DJ, Dickenson HAJ (2015) Phenyl saligenin phosphate induced caspase in cardiomyocyte like cells. Chem Res Toxicol 28:2179-2191

Festoff BW, Suo Z, Citron BA (2001) Plasticity and stabilization of neuromuscular and CNS synapses: interactions between thrombin protease signaling pathways and tissue transglutaminase. Int Rev Cytol 211:154-155

Flaskos J, Nikolaidis E, Harris W, Sachana M, Hargreaves AJ (2011) Effects of sub-lethal neurite outgrowth inhibitory concentrations of chlorpyrifos oxon on cytoskeletal proteins and acetylcholinesterase in differentiating N2a cells. Toxicol Appl Pharmacol 256:330-336

Garcia SJ, Seidler FJ, Crumpton TL, Slotkin TA (2001) Does the developmental neurotoxicity of chlorpyrifos involve glial targets? Macromolecule synthesis, adenylyl cyclase signaling, nuclear transcription factors, and formation of reactive oxygen in C6 glioma cells. Brain Res 891(1-2):54-68 
Giordano G, Afsharinejad Z, Guizzetti M, Vitalone A, Kavanagh TJ, Costa LG (2007) Organophosphorus insecticides chlorpyrifos and diazinon and oxidative stress in neuronal cells in a genetic model of glutathione deficiency. Toxicol Appl Pharmacol 219(2-3):181-189

Glynn P (2000) Neural development and neurodegeneration: two faces of neuropathy target esterase. Prog Neurobiol 61(1):61-74

Grandjean P, Landrigan PJ (2014) Neurobehavioural effects of developmental toxicity. Lancet Neurol 13(3):330-338

Grosso H, Mouradian MM (2012) Transglutaminase 2: biology, relevance to neurodegenerative diseases and therapeutic implications. Pharmacol Therapeut 133(3):392-410

Gupta RC (ed) (2006) Toxicology of organophosphate and carbamate compounds. Elsevier, Amsterdam

Hargreaves AJ (2012) Neurodegenerations induced by organophosphorous compounds. Adv Exp Med Biol 724:189-204

Hargreaves AJ, Fowler MJ, Sachana M, Flaskos J, Bountouri M, Coutts IC, Glynn P, Harris W, McLean WG (2006) Inhibition of neurite outgrowth in differentiating mouse $\mathrm{N} 2$ a neuroblastoma cells by phenyl saligenin phosphate: effects on neurofilament heavy chain phosphorylation, MAP kinase (ERK 1/2) activation and neuropathy target esterase activity. Biochem Pharmacol 71:1240-1247

Harris MO, McLure P, Chessin RL, Corcoran JJ (1997) Toxicological profile for hydraulic fluids. Agency for Toxic Substances and Disease Registry, USA

Harris W, Muñoz D, Bonner PLR, Hargreaves AJ (2009a) Effects of phenyl saligenin phosphate on cell viability and transglutaminase activity in N2a neuroblastoma and HepG2 hepatoma cell lines. Toxicol Vitro 23(8):1559-1563

Harris W, Sachana M, Flaskos J, Hargreaves AJ (2009b) Proteomic analysis of differentiating neuroblastoma cells treated with sub-lethal neurite inhibitory concentrations of diazinon: identification of novel biomarkers of effect. Toxicol Appl Pharmacol 240(2):159-165

Howard AS, Bucelli R, Jett DA, Bruun D, Yang D, Lein PJ (2005) Chlorpyrifos exerts opposing effects on axonal and dendritic growth in primary neuronal cultures. Toxicol Appl Pharmacol 207(2):112-124

Ientile R, Caccamo D, Griffin M (2007) Tissue transglutaminase and the stress response. Amino Acids 33(2):385-394

Jiang W, Duysen EG, Hansen H, Shlyakhtenko L, Schopfer LM, Lockridge O (2010) Mice treated with chlorpyrifos or chlorpyrifos oxon have organophosphorylated tubulin in the brain and disrupted microtubule structures, suggesting a role for tubulin in neurotoxicity associated with exposure to organophosphorus agents. Toxicol Sci 115(1):183-193

Johnson JO, Pioro EP, Boehringer A, Chia R, Feit H, Renton AE, Pliner HA, Abramzon Y, Marangi G, Winborn BJ, Gibbs JR, Nalls MA, Morgan S, Shoai M, Hardy J, Pittman A, Orrell RW, Malaspina A, Sidle KC, Fratta P, Harms MB, Baloh RH, Pestronk A, Weihl CC, Rogaeva E, Zinman L, Drory VE, Borghero G, Mora G, Calvo A, Rothstein JD, Drepper C, Sendtner M, Singleton AB, Taylor JP, Cookson MR, Restagno G, Sabatelli M, Bowser R, Chiò A, Traynor BJ (2014) Mutations in the matrin 3 gene cause familial amyotrophic lateral sclerosis. Nat Neurosci 17(5):664-666

Kamanyire R, Karralliede L (2004) Organphosphate toxicity and occupational exposure. Occup Med 54:69-75

Kim SY, Jeitner TM, Steinert PM (2002) Transglutaminases in disease. Neurochem Int 40(1):85-103

Laemmli UK (1970) Cleavage of structural proteins during the assembly of the head of bacteriophage T4. Nature 227:680-685

Lee I, Eriksson P, Buratovic S, Viberg H (2015) Developmental neurotoxic effects of two pesticides: Behavior and biomolecular studies on chlorpyrifos and carbaryl. Toxicol Appl Pharmacol 299(3):429-438
Lilley GR, Skill J, Griffin M, Bonner PLR (1998) Detection of $\mathrm{Ca}^{2+}$-dependent transglutaminase activity in root and leaf tissue of monocotyledonous and dicotyledonous plants. Plant Physiol 117:1115-1123

Liu F, Xu L, Chen N, Zhou M, Li C, Yang Q, Xie Y, Huang Y, Ma C (2017) Neuronal Fc-epsilon receptor 1 contributes to antigen evoked pruritis in a murine model of ocular allergy. Brain Behav Immun 61:165-175

Lorand L, Graham RM (2003) Transglutaminases: crosslinking enzymes with pleiotropic functions. Nat Rev Mol Cell Biol 4:140-156

Lotti M, Johnson MK (1978) Neurotoxicity of organophosphorus pesticides: predictions can be based on in vitro studies using hen and human enzymes. Arch Toxicol 41(3):215-221

Mahoney SA, Wilkinson M, Smith S, Haynes LW (2000) Stabilization of neurites in cerebellar granule cells by transglutaminase activity: identification of midkine and galectin-3 as substrates. Neurosci 101:141-155

Oh JE, Raja KK, Shin JH, Pollak A, Hengstschläger M, Lubec G (2006) Cytoskeleton changes following differentiation of N1E-115 neuroblastoma cell line. Amino Acids 31(3):289-298

Perry MJ, Mahoney SA, Haynes LW (1995) Transglutaminase C in cerebellar granule neurons: regulation and localization of substrate cross-linking. Neurosci 65:1063-1076

Qiao D, Seidler FJ, Slotkin TA (2001) Developmental neurotoxicity of chlorpyrifos modeled in vitro: comparative effects of metabolites and other cholinesterase inhibitors on DNA synthesis in PC12 and C6 cells. Env Health Perspect 109(9):909-913

Ray DE, Richards PG (2001) The potential for toxic effects of chronic, low-dose exposure to organophosphates. Toxicol Lett 120:343-351

Sachana M, Flaskos J, Alexaki E, Glynn P, Hargreaves AJ (2001) The toxicity of chlorpyrifos towards differentiating mouse N2a neuroblastoma cells. Toxicol Vitro 15(4-5):369-372

Sachana M, Flaskos J, Sidiropoulou E, Yavari CA, Hargreaves AJ (2008) Inhibition of extension outgrowth in differentiating rat C6 glioma cells by chlorpyrifos and chlorpyrifos oxon: effects on microtubule proteins. Toxicol Vitro 22(5):1387-1391

Salton M, Elkron R, Borodina T, Davydov A, Yaspo M-L, Halperin E, Shiloh Y (2011) Matrin 3 binds and stabilizes mRNA. PLoS ONE 6(8):e23882

Saulsbury MD, Heyliger SO, Wang K, Johnson DJ (2009) Chlorpyrifos induces oxidative stress in oligodendrocyte progenitor cells. Toxicol 259(1-2):1-9

Sánchez-Santed F, Colomina MT, Hernández EH (2016) Organophosphate pesticide exposure and neurodegeneration. Cortex 74:417-426

Saunders M, Magnanti BL, Carreira SC, Yang A, Alamo-Hernández U, Riojas-Rodriguez H, Calamandrei G, Koppe JG, Krayer von Krauss M, Keune H, Bartonova A (2012) Chlorpyrifos and neurodevelopmental effects: a literature review and expert elicitation on research and policy. Env Health 11(1):S5

Sindi RA, Harris W, Arnott G, Flaskos J, Lloyd Mills C, Hargreaves AJ (2016) Chlorpyrifos- and chlorpyrifos oxon-induced neurite retraction in pre-differentiated N2a cells is associated with transient hyperphosphorylation of neurofilament heavy chain and ERK 1/2. Toxicol Appl Pharmacol 308:20-31

Slaughter TF, Achyuthan KE, Lai TS, Greenberg CS (1992) A microtiter plate transglutaminase assay using 5-(biotinamido) pentylamine as substrate. Analyt Biochem 205:166-171

Slotkin TA, Seidler FJ (2007) Comparative developmental neurotoxicity of organophosphates in vivo: transcriptional responses of pathways for brain cell development, cell signaling, cytotoxicity and neurotransmitter systems. Brain Res Bull 72(4-6):232-274 
Sogorb MA, Pamies D, Estevan J, Vilanova E (2016) Roles of NTE protein and encoding gene in development and neurodevelopmental toxicity. Chem Biol Interact 259:352-357

Stoscheck CM (1990) Quantitation of protein. Meth Enzymol 182:50-68

Sugitani K, Matsukawa T, Koriyama Y, Shintani T, Nakamura T, Noda M, Kato S (2006) Upregulation of retinal transglutaminase during the axonal elongation stage of goldfish optic nerve regeneration. Neurosci 142(4):1081-1092

Towbin H, Staehelin T, Gordon J (1979) Electrophoretic transfer of proteins from polyacrylamide gels to nitrocellulose sheets: procedure and some applications. Proc Natl Acad Sci USA 76:4350-4354

Tucholski J, Johnson GVW (2003) Tissue transglutaminase directly regulates adenylyl cyclase resulting in enhanced CREB activation. J Biol Chem 278(29):26838-26843

Tucholski J, Lesort M, Johnson GVW (2001) Tissue transglutaminase is essential for neurite outgrowth in human neuroblastoma $\mathrm{SH}$ SY5Y cells. Neurosci 102(2):481-491

Valencia CA, Ju W, Liu R (2007) Matrin3 is a $\mathrm{Ca}^{2+} /$ calmodulin-binding protein cleaved by caspases. Biochem Biophys Res Commun 361:281-286

Van der Klejj H, Charles N, Karimi K, Mao YK, Foster J, Janssen L, Yang PC, Kunze W, Rivera J, Bienenstock J (2010) Evidence for neuronal expression of functional Fc $(\varepsilon$ and $\gamma$ ) receptors. J Allergy Clin Immunol 125(3):757-760

Vyas FS, Hargreaves AJ, Bonner PLR, Boocock DJ, Coveney C, Dickenson JM (2016) A1 adenosine receptor-induced phosphorylation and modulation of transglutaminase 2 activity in $\mathrm{H} 9 \mathrm{c} 2$ cells: a role in cell survival. Bioch Pharmacol 107:41-58

Vyas FS, Nelson CP, Freeman F, Boocock DJ, Hargreaves AJ, Dickenson JM (2017) $\beta 2$-adrenoceptor-induced modulation of transglutaminase 2 transamidase activity in cardiomyoblasts. Eur J Pharmacol 813:105-121

Wang M, Ye R, Barron E, Baumeister P, Mao C, Luo S, Fu Y, Luo B, Dubeau L, Hinton DR, Lee AS (2010) Essential role of the unfolded protein response regulator GRP78/BiP in protection from neuronal apoptosis. Cell Death Diff 17:488-498

Weng WC, Lee WT, Hsu WM, Chang BE, Lee H (2011) Role of glucose-regulated Protein 78 in embryonic development and neurological disorders. J Formosan Med Assoc 110(7):428-437

Xu B, Chen S, Luo Y, Chen Z, Liu L, Zhou H, Chen W, Shen T, Han X, Chen L, Huang S (2011) Calcium signaling is involved in cadmium-induced neuronal apoptosis via induction of reactive oxygen species and activation of MAPK/mTOR network. PLoS ONE 6(4):e19052

Yang D, Howard A, Bruun D, Ajua-Alemanj M, Pickart C, Lein PJ (2008) Chlorpyrifos and chlorpyrifos-oxon inhibit axonal growth by interfering with the morphogenic activity of acetylcholinesterase. Toxicol Appl Pharmacol 228(1):32-41

Zeligs MA (1938) Upper motor neuron sequelae in "Jake" paralysis: a clinical follow up study. J Nerv Ment Dis 87:464-470

Zhang X, Szabo E, Michalak M, Opas M (2007) Endoplasmic reticulum stress during the embryonic development of the central nervous system in the mouse. Int J Dev Neurosci 25(7):455-463

Publisher's Note Springer Nature remains neutral with regard to jurisdictional claims in published maps and institutional affiliations. 